\title{
Prediksi Financial Distress pada Perusahaan Manufaktur di Bursa Efek Indonesia
}

\author{
Randy Kurnia Permana, Nurmala Ahmar, Syahril Djaddang \\ Magister Akuntansi Universitas Pancasila \\ randysatriandy@gmail.com, ahmarnurmala@gmail.com, \\ Djaddangsyahril@gmail.com
}

\begin{abstract}
This study aims to identify, analyze, demonstrate and test the differences in health status between the model results Grover, Springate, and Zmijewski. The model used by investors who will invest in the company. This study has a characteristic that is tested three models and find the one best model. Data was tested using chi-square test. Results showed Hypothesis 1 accepted that there are differences in health status in the test model of Grover, Springate, and Zmijewski on manufacturing companies listed on the Stock Exchange 2006-2015. Model Springate is the best predictive model than the model Grover and Springate, because it has more components than the other models and models Springate have EBIT To Current Liabilities component is how much profit the ability to pay debts. This component is a very important component to see financial distress, due to financial distress occur because one debt that not covered by the company.
\end{abstract}

Keywords: financial distress, Grover model, Springate model, Zmijewski model

\begin{abstract}
Abstrak
Penelitian ini bertujuan untuk mengetahui, menganalisis, membuktikan dan menguji perbedaan hasil status kesehatan antara model Grover, Springate, dan Zmijewski. Model tersebut digunakan oleh investor yang akan menanamkan modalnya di perusahaan. Data penelitian diuji menggunakan uji chi square. Hasil penelitian menunjukkan hipotesis 1 diterima yaitu terdapat perbedaan status kesehatan pada pengujian model Grover, Springate, dan Zmijewski pada perusahan manufaktur yang terdaftar di BEI tahun 2006-2015. Model Springate merupakan model prediksi terbaik dibandingkan model Grover dan Springate, karena mempunyai komponen lebih banyak dari kedua model lainnya dan model Springate mempunyai komponen EBIT To Current Liabilities yaitu seberapa besar kemampuan laba dalam membayar hutang perusahaan. Komponen ini adalah komponen yang sangat penting untuk melihat kesulitan keuangan, karena kesulitan keuangan salah satunya terjadi karena hutang yang tidak tercakup oleh perusahaan.
\end{abstract}

Kata Kunci: kesulitan keuangan, model Grover, model Springate, model Zmijewski

Diterima: 02 Februari 2017; Direvisi: 08 Maret 2017; Disetujui: 10 April 2017 


\section{PENDAHULUAN}

Setiap perusahaan didirikan dengan harapan akan menghasilkan keuntungan sehingga mampu bertahan atau berkembang dalam jangka panjang dan tidak mengalami likuidasi. Kenyataannya, asumsi tersebut tidak selalu terjadi dengan baik sesuai harapan. Seringkali perusahaan yang telah beroperasi dalam jangka waktu tertentu terpaksa bubar atau dilikuidasi karena mengalami kesulitan keuangan yang berujung pada kebangkrutan. Analisis mengenai gejala-gejaja kebangkrutan harus dilakukan, guna mengantisipasi terjadinya kebangkrutan dimasa yang akan datang. Cara yang dilakukan adalah dengan menganalisis rasiorasio keuangan perusahaan dengan model tertentu seperti dalam penelitian ini. Hal ini mengingat tidak sedikit fenomena-fenomena kebangkrutan yang dialami perusahaan-perusahaan di Indonesia (Adriana, 2012).

Fenomena yang baru baru ini terjadi di Indonesia adalah delisting beberapa perusahaan pada tahun 2015. Delisting adalah apabila saham yang tercatat di Bursa mengalami penurunan kriteria sehingga tidak memenuhi persyaratan pencatatan, maka saham tersebut dapat dikeluarkan dari pencatatan di Bursa. Tahun 2015 Bursa Efek Indonesia (BEI) mengeluarkan 3 perusahaan dari Bursa yaitu : PT. Davomas Abadi, Tbk (DAVO), PT. Bank Ekonomi Raharja, Tbk (BAEK), dan PT. Unitex, Tbk (UNTX).

Pada Kasus DAVO, Bursa efek memberlakukan proses delisting paksa (Forced Delisting) karena keberlangsungan usaha yang mengkhawatirkan dan dalam pencarian alamat untuk perusahaannya sendiri tidak jelas. Davo listing di bursa efek sejak tahun 1994 dan resmi di keluarkan oleh BEI pada Januari 2015. Pada Kasus UNTX yang delisting baru baru ini pada Desember 2015 dikarenakan akibat kerugian operasional yang dialami perusahaan selama beberapa tahun terakhir yang mengakibatkan ekuitas di dalam neraca menjadi negatif dan tidak lagi dapat membagikan deviden ke pemegang saham.

Kondisi Indonesia saat ini sangat rawan terjadinya kesulitan keuangan (financial distress) pada beberapa perusahaan nasional. Hal ini merupakan akibat dari pulihnya Amerika Serikat dari krisis, yang menyebabkan negara berkembang seperti Indonesia terkena dampaknya yang menyebabkan mata uang rupiah 
terpuruk yaitu 1 dolar menjadi Rp. 13.000,00. Kondisi ini di perparah dengan ekspor yang semakin anjlok dan juga harga komoditas ekspor yang juga anjlok di pasar komoditas dunia. Pailitnya suatu perusahaan dapat terlihat dari delistingnya perusahaan tersebut dari BEI. Walaupun delisting bukan hanya berarti perusahaan tersebut tidak memiliki keberlangsungan usaha menurut BEI, tetapi ada juga yang lebih memilih menjadi perusahaan tertutup (go private) karena alasan tertentu. Berikut ini adalah daftar perusahaan yang delisted dan berindikasi bangkrut dari tahun 2009-2015 baik delisted karena tidak memiliki keberlangsungan usaha, maupun yang memilih Go Private :

\section{Gambar 1. Perkembangan Perusahaan Bangkrut Tahun 2009-2015}

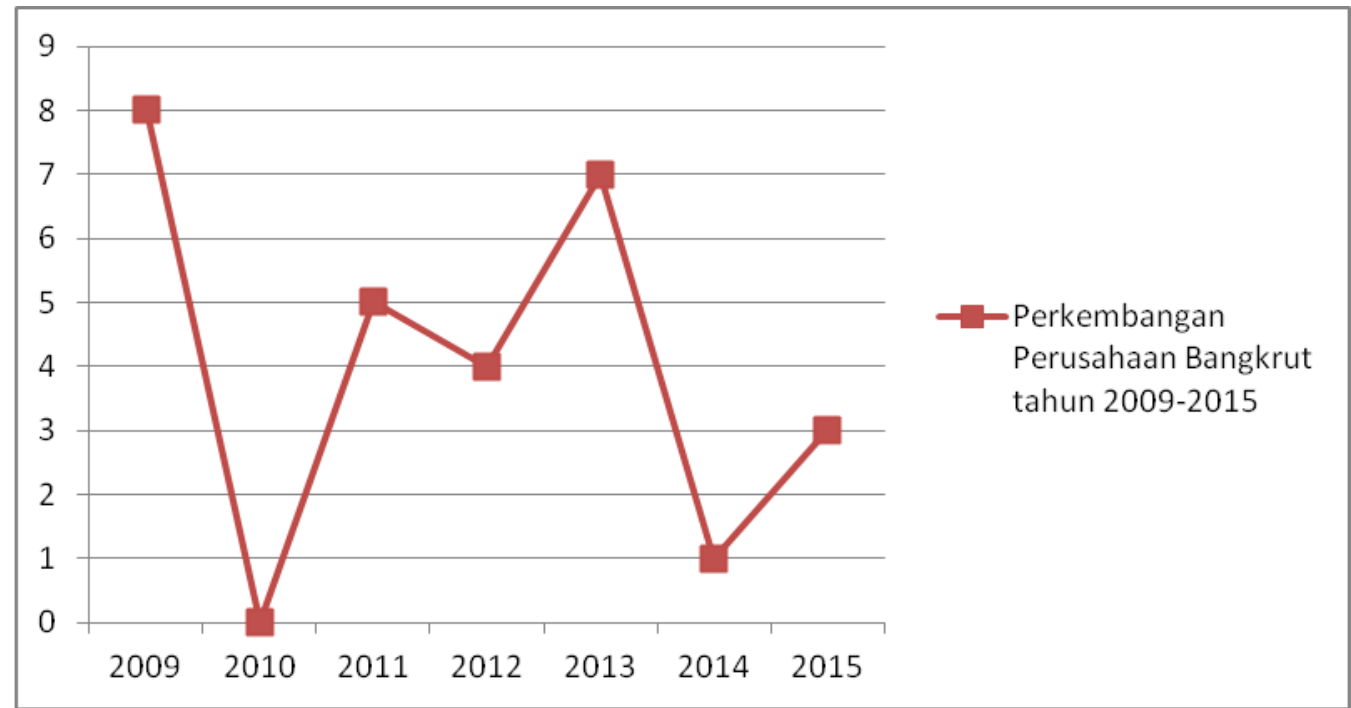

Sumber: Indonesia Capital Market Directory

Gambar 1 memperlihatkan bahwa perkembangan perusahaan yang delisted atau diindikasikan bangkrut dari tahun 2009-2015 terus mengalami fluktuasi. Paling banyak terjadi di tahun 2009 hal ini disebabkan karena Amerika yang mengalami krisis sehingga menyebabkan kondisi rupiah anjlok yang menjadi akibat perusahaan di Indonesia terkena imbas yang cukup parah. Tahun 2010 perusahaan terdaftar cukup bisa bertahan, tetapi tahun 2011 terdapat 5 perusahaan yang delisted.

Di tahun 2012 pun masih terdapat perusahaan delisted walaupun turun menjadi 4 perusahaan. Ternyata tren tersebut tidak berlanjut di tahun berikutnya yaitu tahun 2013. Tahun 2013 perusahaan yang delisted kembali bertambah menjadi 7 perusahaan. Hal tersebut akibat dampak dari bangkitnya ekonomi 
Amerika Serikat yang kembali membuat Rupiah terpuruk. Pada tahun berikutnya yaitu 2014 perusahaan yang delisted turun menjadi 1 perusahaan, dan tahun 2015 hanya sebanyak 3 perusahaan.

Kesulitan keuangan terjadi sebelum kebangkrutan. Model kesulitan keuangan perlu untuk dikembangkan, karena dengan mengetahui keadaan kesulitan keuangan perusahaan sejak dini diharapkan dapat dilakukan tindakan-tindakan untuk mengantisipasi kondisi yang mengarah pada kebangkrutan. Kesulitan keuangan terjadi sebelum kebangkrutan. (Rahayu \& Putri, 2016). Kondisi kesulitan keuangan dapat di kenali lebih awal dengan menggunakan suatu model tertentu. Model ini dapat membantu calon investor dan juga dan kreditur untuk menanamkan modalnya agar tidak terjebak dalam kondisi kesulitan keuangan tersebut. Model tersebut di kembangkan oleh, Jeffrey S Grover (Grover) tahun 1968, Springate tahun 1981, Zmijewski tahun 1983 (Darsono \& Ashari, 2005).

Model Grover di kembangkan oleh Jeffrey S Grover pada tahun 1968. Model Grover diciptakan dengan pendesainan dan penilaian ulang terhadap model Altman Z-Score. Model Grover mengkategorikan perusahaan dalam keadaan bangkrut jika diperoleh skor kurang atau sama dengan -0,02 (Z -0,02). Model Selanjutnya adalah Model Zmijewski Model prediksi yang dihasilkan oleh Zmijewski (1984) merupakan hasil riset selama 20 tahun yang ditelaah ulang (Wulandary dan Nur, 2014). Zmijewski menggunakan rasio keuangan return on asset (ROA), leverage, dan likuiditas untuk mendapatkan pola yang lebih tepat (Zmijewski, 1984). Rasio keuangan ini dipilih bukan berdasarkan teori tetapi berasal dari pengalaman dan penelitian sebelumnya (Zmijewski, 1984).

Model selanjutnya yang bisa dipakai untuk memprediksi kondisi Kesulitan keuangan adalah Model Springate. Metode ini merupakan pengembangan dari metode Altman dengan menggunakan multiple discriminant analysis (MDA) (Springate, 1978). Pada awalnya, metode ini menggunakan 19 rasio keuangan populer namun, setelah melakukan pengujian kembali akhirnya Springate memilih 4 rasio yang digunakan dalam menentukan kriteria perusahaan termasuk dalam kategori perusahaan yang sehat atau perusahaan yang berpotensi bangkrut (Wulandary dan Nur, 2014). 
Penelitian dengan topik sejenis tentang kesulitan keuangan juga telah banyak dilakukan, seperti penelitian dari Citrawati dan Gede (2014) dengan membandingkan model Altman, Springate, dan Zmijewski pada PT. Fast Food Indonesia, Tbk. Hasil Penelitian menunjukkan bahwa kinerja perusahaan secara garis besar dalam keadaan sehat atau tidak berpotensi bangkrut hal ini dtunjukkan dari hasil pengujian menggunakan ketiga metode yaitu metode Z- score Altman, Springate, Zmijewski.

Penelitian selanjtunya dilakukan oleh Lukman dan Ahmar (2015) dengan membandingkan model prediksi kebangkrutan mana yang terkuat, yaitu antara model Fullmer H-Score dan juga Springate terhadap perusahaan pertambangan yang terdaftar di BEI dari tahun 2011-2015. Hasil penelitian menunjukkan bahwa hasil perhitungan menggunakan model Fullmer H-Score kebanyakan perusahaan pertambangan pada tahun 2011-2014 perusahaan diindikasi mengalami kebangkrutan $26.35 \%$ dan $73.65 \%$ perusahaan diprediksi sebagai perusahaan yang sehat dan berdasarkan perhitungan mengunakan model Springate dari tahun 20112014 menghasilkan $45.27 \%$ perusahaan pertambangan diprediksi sebagai perusahaan yang sehat dan $54.73 \%$ diprediksi sebagai perusahaan yang bangkrut.

Kontribusi penelitian ini bagi perusahaan adalah dapat memberikan gambaran mengenai kondisi keuangan perusahaan. Hal ini dapat menjadi referensi bagi perusahaan untuk memperbaiki kinerja ke depan. Kontribusi bagi investor adalah dapat memberikan rekomendasi model yang sesuai untuk mengukur financial distress perusahaan serta membantu dalam membuat keputusan investasi. Kontribusi selanjutnya adalah bagi kreditor yaitu dapat memberikan informasi tentang kesehatan perusahaan yang mempengruhi keputusan pemberian kredit agar terhindar dari kerugian dalam pengembalian kredit. Kontribusi terkahir adalah bagi akademisi yaitu dapat memberikan referensi untuk melakukan penelitian selanjutnya.

Berdasarkan latar belakang diatas prediksi kesulitan keuangan sangat penting sekali untuk dilakukan terutama bagi investor yang akan menanamkan modalnya di sebuah perusahaan. Penelitian mengenai kesulitan keuangan telah banyak dilakukan di Indonesia, tetapi penelitian mengenai kesulitan keuangan 
dengan membandingkan beberapa model prediksi dan juga mengambil rentang waktu 10 tahun sebagai bahan penelitian masih sangat terbatas. Oleh karena itu penelitian ini berupaya mengetahui prediksi kesulitan keuangan dengan menggunakan model Grover, model Springate, dan model Zmijewski dari tahun 20062015.

\section{METODE}

Sampel pada penelitian ini adalah seluruh perusahaan manufaktur yang terdaftar di BEI dari tahun 2006-2015 termasuk perusahaan manufaktur yang delisting dari tahun 2006-2015 sampai perusahaan manufaktur yang baru IPO maupun relisting dari tahun 2006-2015.

Analisis data dalam penelitian ini menggunakan Model Grover, Springate, dan Zmijewski digunakan untuk melihat status kesehatan pada perusahaan manufaktur yang terdaftar di BEI tahun 2006-2015, kemudian di uji beda menggunakan uji chi-square. Berikut adalah ketiga model tersebut:

\section{Model Springate}

$S=1,03 A+3,07 B+0,66 C+0,4 D$

Keterangan :

A = Working capital / Total asset

$\mathrm{B}=$ Net profit before interest and taxes / Total asset

$\mathrm{C}=$ Net profit before taxes /Current liabilities

$\mathrm{D}=$ Sales $/$ Total asset

Dengan cut off Jika nilai Springate lebih besar dari 0,862 maka perusahaan masuk dalam kategori perusahaan sehat dan jika nilai Springate lebih kecil dari 0,862 maka perusahaan masuk ke dalam kategori perusahaan tidak sehat atau berpotensi sebagai perusahaan bangkrut

\section{Model Grover}

Score $=1,650$ X1 + 3,404 X3 +0,016 ROA + 0,057

Keterangan :

X1 =Working Capital / Total asset 
X3 = Earning before interest and taxes/Total asset

$\mathrm{ROA}=$ Net income/ Total asset

Dengan cut off jika skor kurang atau sama dengan -0,02 ( $Z \leq-0,02)$ maka perusahaan tersebut terindikasi tidak sehat sedangkan jika untuk perusahaan yang dikategorikan dalam keadaan sehat adalah lebih atau sama dengan 0,01 $(Z \geq 0,01)$ (Puspitasari, 2014).

\section{Model Zmijewski}

$X=-4,3-4,5 \times 1+5,7 X 2-0,004 X 3$

Dimana :

$\mathrm{X} 1=$ ROA (Return on Asset)

$\mathrm{X} 2$ = Leverage (Debt Ratio)

X3 = Likuiditas (Current Ratio)

Dengan cut off jika skor yang diperoleh ini melebihi 0 maka perusahaan diprediksi berpotensi mengalami kebangkrutan. Sebaliknya, jika sebuah perusahaan memiliki skor yang kurang dari 0 maka perusahaan diprediksi tidak berpotensi untuk mengalami kebangkrutan (Wulandary dan Nur, 2014).

\section{Uji Chi-Square}

Uji beda dilakukan setelah mendapatkan hasil status kesehatan dari perusahaan manufaktur yang di uji melalui 3 model. Uji beda yang digunakan dalam penelitian ini adalah uji Chi-Square. Pengujian dilakukan dengan melihat status kesehatan dari perusahaan manufaktur yang berasal dari 3 model yang kemudian dikategorikan dengan angka 1 yang mendapat status tidak sehat dan angka 0 yang mendapat status sehat. Hasil tersebut kemudian dibandingkan untuk melihat apakah terdapat perbedaan antara model Grover, Springate, dan Zmijewski.

\section{HASIL DAN PEMBAHASAN}

Total keseluruhan perusahaan yang dihitung menggunakan model Grover adalah 1483 perusahaan selama 10 tahun terakhir, dengan rincian 1313 perusahaan mempunyai status sehat dan 170 perusahaan mempunyai status tidak sehat atau 
88.5\% persen untuk status sehat dan $11.5 \%$ untuk perusahaan yang mempunyai status tidak sehat. Tahun 2006 merupakan tahun dimana terdapat perusahaan yang mempuyai status tidak sehat terbanyak. Pada tahun ini terdapat 28 perusahaan dan persentasenya adalah $16.5 \%$, lalu untuk perusahaan yang sehat terkecil berada pada tahun 2006 juga dengan 113 perusahaan dan persentase 8.6\%.

Tabel 1. Status Kesehatan Perusahaan Manufaktur Model Grover

\begin{tabular}{|c|c|c|c|c|c|c|}
\hline \multirow[t]{2}{*}{ Tahun } & \multicolumn{2}{|c|}{ Status } & \multicolumn{2}{|c|}{ Persentase Pertahun } & \multicolumn{2}{|c|}{$\begin{array}{l}\text { Persentase } \\
\text { Keseluruhan }\end{array}$} \\
\hline & Sehat & Tidak Sehat & Sehat & Tidak Sehat & Sehat & Tidak Sehat \\
\hline 2006 & 113 & 28 & $80.1 \%$ & $19.9 \%$ & $8.6 \%$ & $16.5 \%$ \\
\hline 2007 & 126 & 25 & $83.4 \%$ & $16.6 \%$ & $9.6 \%$ & $14.7 \%$ \\
\hline 2008 & 130 & 18 & $87.8 \%$ & $12.2 \%$ & $9.9 \%$ & $10.6 \%$ \\
\hline 2009 & 127 & 20 & $86.4 \%$ & $13.4 \%$ & $9.7 \%$ & $11.8 \%$ \\
\hline 2010 & 131 & 14 & $90.3 \%$ & $9.7 \%$ & $10 \%$ & $8.2 \%$ \\
\hline 2011 & 133 & 13 & $91.1 \%$ & $8.9 \%$ & $10.1 \%$ & $7.6 \%$ \\
\hline 2012 & 136 & 13 & $91.3 \%$ & $8.7 \%$ & $10.4 \%$ & $7.6 \%$ \\
\hline 2013 & 136 & 11 & $92.5 \%$ & $7.5 \%$ & $10.4 \%$ & $6.5 \%$ \\
\hline 2014 & 141 & 14 & $91 \%$ & $9 \%$ & $10.7 \%$ & $8.2 \%$ \\
\hline 2015 & 140 & 14 & $90.9 \%$ & $9.1 \%$ & $10.7 \%$ & $8.2 \%$ \\
\hline
\end{tabular}

Sumber : Data diolah (2016)

Total keseluruhan perusahaan yang dihitung menggunakan model Springate adalah 1491 perusahaan selama 10 tahun terakhir, dengan rincian 1007 perusahaan mempunyai status sehat, 484 perusahaan mempunyai status tidak sehat atau $67.5 \%$ persen untuk status sehat dan $32.5 \%$ untuk perusahaan yang mempunyai status tidak sehat.

Tabel 2. Status Kesehatan Perusahaan Manufaktur Model Springate

\begin{tabular}{ccccccc}
\hline \multirow{2}{*}{ Tahun } & \multicolumn{2}{c}{ Status } & \multicolumn{2}{c}{ Persentase Pertahun } & \multicolumn{2}{c}{ Persentase Keseluruhan } \\
& Sehat & Tidak Sehat & Sehat & Tidak Sehat & Sehat & Tidak Sehat \\
\hline 2006 & 80 & 62 & $56.3 \%$ & $43.7 \%$ & $7.9 \%$ & $12.8 \%$ \\
2007 & 99 & 53 & $65.1 \%$ & $34.9 \%$ & $9.8 \%$ & $11 \%$ \\
2008 & 99 & 58 & $66.2 \%$ & $33.8 \%$ & $9.7 \%$ & $10.3 \%$ \\
2009 & 107 & 41 & $72.3 \%$ & $27.7 \%$ & $10.6 \%$ & $8.5 \%$ \\
2010 & 104 & 42 & $71.2 \%$ & $28.8 \%$ & $10.3 \%$ & $8.7 \%$ \\
2011 & 117 & 29 & $80.1 \%$ & $19.9 \%$ & $11.6 \%$ & $6 \%$ \\
2012 & 112 & 38 & $74.7 \%$ & $25.3 \%$ & $11.1 \%$ & $7.9 \%$ \\
2013 & 95 & 54 & $63.8 \%$ & $36.2 \%$ & $9.4 \%$ & $11.2 \%$ \\
2014 & 113 & 42 & $72.9 \%$ & $27.1 \%$ & $11.2 \%$ & $8.7 \%$ \\
2015 & 82 & 73 & $53.9 \%$ & $47.1 \%$ & $8.1 \%$ & $15.1 \%$ \\
\hline
\end{tabular}

Sumber :Data diolah 
Total keseluruhan perusahaan yang dihitung menggunakan model Zmijewski adalah 1491 perusahaan selama 10 tahun terakhir, dengan rincian 1215 perusahaan mempunyai status sehat, 276 perusahaan mempunyai status tidak sehat atau $81,5 \%$ persen untuk status sehat dan 18,5\% untuk perusahaan yang mempunyai status tidak sehat. Tahun yang mempuyai status tidak sehat terbanyak adalah tahun 2007 dengan 33 perusahaan dan persentasenya adalah 13\%, lalu untuk perusahaan yang sehat terkecil berada pada tahun 2006 dengan 109 perusahaan dan persentase 9\%.

Tabel 3. Status Kesehatan Perusahaan Manufaktur Model Zmijewski

\begin{tabular}{ccccccc}
\hline \multirow{2}{*}{ Tahun } & \multicolumn{2}{c}{ Status } & \multicolumn{2}{c}{ Persentase Pertahun } & \multicolumn{2}{c}{ Persentase Keseluruhan } \\
& Sehat & Tidak Sehat & Sehat & Tidak Sehat & Sehat & Tidak Sehat \\
\hline 2006 & 109 & 33 & $76,8 \%$ & $23,2 \%$ & $9,0 \%$ & $12,0 \%$ \\
2007 & 116 & 36 & $76,3 \%$ & $26,7 \%$ & $9,5 \%$ & $13 \%$ \\
2008 & 112 & 36 & $75,7 \%$ & $24,3 \%$ & $9,2 \%$ & $13 \%$ \\
2009 & 120 & 28 & $81,1 \%$ & $18,9 \%$ & $9,9 \%$ & $10,1 \%$ \\
2010 & 122 & 24 & $83,6 \%$ & $16,4 \%$ & $10,0 \%$ & $8,7 \%$ \\
2011 & 124 & 22 & $84,9 \%$ & $15,1 \%$ & $10,2 \%$ & $8 \%$ \\
2012 & 128 & 22 & $85,3 \%$ & $14,7 \%$ & $10,5 \%$ & $8 \%$ \\
2013 & 123 & 26 & $82,6 \%$ & $17,4 \%$ & $10,1 \%$ & $9,4 \%$ \\
2014 & 132 & 23 & $85,2 \%$ & $14,8 \%$ & $10,9 \%$ & $8,3 \%$ \\
2015 & 129 & 26 & $83,2 \%$ & $16,8 \%$ & $10,6 \%$ & $9,4 \%$ \\
\hline
\end{tabular}

Sumber : Data diolah (2016)

Berdasarkan Tabel 4, dapat diketahui bahwa terdapat 4465 perusahaan selama pengamatan 10 tahun terkahir yaitu dari tahun 2006-2015. Data tersebut sudah dikurangi perusahaan yang mendapat status kesehatan grey area pada model Grover karena penelitian ini hanya menggunakan dua status kesehatan yaitu sehat dan tidak sehat. Berdasarkan data di atas dapat dilihat bahwa terdapat perbedaaan dari ketiga model tersebut. Model Grover memprediksi perusahaan dengan status sehat terbanyak yaitu sebanyak 1313 perusahaan atau sebanyak $37.1 \%$ selama 10 tahun terkahir. Sedangkan Zmijewski memprediksi sebanyak 1215 perusahaan atau 34,4\% dan Springate sebanyak 1007 perusahaan atau 28.5\%. 
Perbedaan juga terlihat dari hasil status tidak sehat yaitu model Grover memprediksi 170 perusahaan manufaktur mempunyai status tidak sehat atau sebesar 18,3\% selama pengamatan 10 tahun terakhir. Model Springate memprediksi 484 perusahaan mengalami status tidak sehat atau 52\%, dan Zmijewski mempreidksi 276 perusahaan atau 29,7\% selama pengamatan 10 tahun terakhir dari tahun 2006-2015.

Tabel 4. Tingkat Kesulitan Keuangan Model Grover, Springate dan Zmijewski Perusahaan Manufaktur

\begin{tabular}{clcccc}
\hline \multirow{2}{*}{ Status Kesehatan } & \multicolumn{3}{c}{$\begin{array}{c}\text { Metode } \\
\text { Grover }\end{array}$} & $\begin{array}{c}\text { Springate } \\
\text { Zmijewski }\end{array}$ & Total \\
\hline \multirow{3}{*}{ Sehat } & Jumlah sampel & 1313 & 1007 & 1215 & 3535 \\
& Status kesehatan & $37.1 \%$ & $28.5 \%$ & $34.4 \%$ & $100.0 \%$ \\
& Metode & $88.5 \%$ & $67.5 \%$ & $81.5 \%$ & $79.2 \%$ \\
\hline \multirow{2}{*}{ Tidak } & Jumlah sampel & 170 & 484 & 276 & 930 \\
Sehat & Status kesehatan & $18.3 \%$ & $52.0 \%$ & $29.7 \%$ & $100.0 \%$ \\
& Metode & $11.5 \%$ & $32.5 \%$ & $18.5 \%$ & $20.8 \%$ \\
\hline \multirow{2}{*}{ Total } & Jumlah sampel & 1483 & 1491 & 1491 & 4465 \\
& Status kesehatan & $33.2 \%$ & $33.4 \%$ & $33.4 \%$ & $100.0 \%$ \\
& Metode & $100.0 \%$ & $100.0 \%$ & $100.0 \%$ & $100.0 \%$ \\
\hline
\end{tabular}

Sumber: Data diolah (2016)

Selain melihat tabel crosstabulation pada Tabel 4, penelitian ini turut pula melakukan uji beda menggunakan uji chi square. Uji ini dilakukan melihat apakah ada perbedaaan dari ketiga model tersebut. Hasil uji Chi-Square dapat dilihat dalam Tabel 5.

Tabel 5. Hasil Uji Chi-Square

\begin{tabular}{lccc}
\hline & Value & df & $\begin{array}{c}\text { Asymp. Sig. (2- } \\
\text { sided) }\end{array}$ \\
\hline Pearson Chi-Square & $206.089 a$ & 2 & .000 \\
Likelihood Ratio & 205.019 & 2 & .000 \\
Linear-by-Linear Association & 22.191 & 1 & .000 \\
N of Valid Cases & 4465 & & \\
\hline
\end{tabular}

a. 0 cells $(.0 \%)$ have expected count less than 5 . The minimum expected count is 308.89 .

Sumber : Data diolah (2016) 
Berdasarkan hasil pada Tabel 5, dapat dilihat bahwa nilai Pearson ChiSquare mempunyai nilai signifikansi (Asymp. Sig. 2-sided) sebesar 0,000. Syarat yang harus dipenuhi agar dikatakan signifikan adalah nilai signifikansi (Asymp. Sig. 2 -sided $)<0,05$. Dapat disimpulkan bahwa hipotesis 1 diterima yaitu terdapat perbedaan status kesehatan pada pengujian model Grover, Springate, dan Zmijewski pada perusahan manufaktur yang terdaftar di BEI tahun 2006-2015. Perbedaan dalam model tersebut dikarenakan masing masing model mempunyai komponen yang berbeda-beda. Pada model Grover dan Springate sama sama menekankan pada seberapa besar kemampuan aset dalam menghasilkan laba.

Walaupun menekankan hal yang sama tetapi Springate mempunyai 4 komponen sedangkan Grover mempunyai 3 komponen. Pada model Zmijewski menekankan pada seberapa besar kemampuan aset dalam membayar hutangnya. Berdasarkan hasil analisa diatas didapatkan hasil bahwa hipotesis 1 diterima yaitu terdapat perbedaan pengujian model Grover, Springate, dan Zmijewski pada perusahan manufaktur yang terdaftar di BEI tahun 2006-2015. Model tersebut dapat dikatakan berhasil dan relevan apabila perusahaan yang mendapat kategori tidak sehat delisted dari Bursa Efek.

Tabel 6. Tabel Siginfikansi Uji Chi-Square tahun 2006-2015

\begin{tabular}{cccc}
\hline No & Tahun & Signifikansi & Keterangan \\
\hline 1 & 2015 & 0.000 & Berbeda \\
2 & 2014 & 0.000 & Berbeda \\
3 & 2013 & 0.000 & Berbeda \\
4 & 2012 & 0.000 & Berbeda \\
5 & 2011 & 0.029 & Berbeda \\
6 & 2010 & 0.000 & Berbeda \\
7 & 2009 & 0.009 & Berbeda \\
8 & 2008 & 0.000 & Berbeda \\
9 & 2007 & 0.001 & Berbeda \\
10 & 2006 & 0.000 & Berbeda
\end{tabular}

Sumber : Data diolah (2016) 
Berdasarkan hasil analisa di atas didapatkan hasil bahwa hipotesis 1 diterima yaitu terdapat perbedaan pengujian model Grover, Springate, dan Zmijewski pada perusahan manufaktur yang terdaftar di BEI tahun 20062015. Hasil tersebut juga dapat terlihat pada Tabel 6. Berdasarkan data di atas dapat terlihat bahwa Uji Chi-Square dari tahun 2006-2015 mempunyai status berbeda dengan nilai signifikansi berada $<0,05$. Dengan nilai siginfikansi tersebut dapat dibuat kesimpulan bahwa ada beda pada pengujian model tersebut. Model tersebut dapat dikatakan berhasil dan relevan apabila perusahaan yang mendapat kategori tidak sehat delisted dari Bursa Efek.

Berdasarkan data yang berisikan 7 perusahaan yang delisted dari tahun 2011 sampai dengan tahun 2015, dapat diketahui bahwa hasil yang didapat menggunakan model Grover, Springate, dan Zmijeski sangat beragam. Dari 7 perusahaan yang delisted di Bursa Efek Indonesia, 3 perusahaan yang delisted dan diprediksi mengalami kesulitan keuangan mendapatan hasil yang lebih baik dengan model Springate yaitu Davomas Abadi, Surya Intrindo Makmur, dan Dynaplast. Model Springate mendapatkan hasil yang lebih baik untuk status tidak sehat dibandingkan ketiga model lainnya. Sehingga dapat dikatakan bahwa model Springate merupakan model terbaik dalam memprediksi kesulitan keuangan pada perusahaan manufaktur.

Pada kasus Aqua Golden Missisipi merupakan kasus yang menarik. Pasalnya Aqua delisted dari bursa karena memilih untuk menjadi Go Private atau Voluntary Deslited yaitu keluar dari bursa secara sukarela karena dianggap sudah dalam kondisi yang mapan. Dengan menjadi perusahaan tertutup maka Aqua tidak lagi harus melaporkan kewajiban dan pengungkapan kepada publik yang memakan biaya besar dan juga tidak diwajibkan membayarkan deviden kepada pemegang saham.

Secara umum 3 model tersebut mampu memprediksi terjadinya kesulitan keuangan walaupun mempunyai hasil yang berbeda. Pada 7 perusahaan 
yang delisted di Bursa Efek, 3 diantaranya diprediksi lebih baik dengan menggunakan model Springate, sedangkan 4 perusahaan lainnya mempunyai hasil yang sama yaitu pada Unitex, Panasia Filament Inti, Surabaya Agung Industry, dan Aqua Golden Missisipi.

Hal tersebut sejalan dengan penelitian terdahulu dari Imanzadeh dan Sepehri (2011). Berdasarkan penelitian tersebut benar adanya terdapat perbedaaan pada model prediksi financial distress. Dalam penelitian tersebut dibandingkan dua model yaitu model Springate dan model Zmijewski dengan populasinya adalah perusahaan yang terdaftar di bursa efek Tehran. Dalam penelitian tersebut juga dijelaskan bahwa model Springate lebih konservatif dalam pengujian dibandingkan model Zmijewski. Hasil tersebut berbeda dengan penelitian Yami (2013). Menurut Yami model yang paling cocok meneliti financial distress adalah model Zmijewski. Hasil penelitian dari Husein dan Pambekti (2014) juga mendapatkan hasil bahwa model yang terbaik adalah model Zmijewski. Karena model Zmijewski menekankan rasio leverage pada perhitungannya.

Hasil penelitian ini konsisten dengan hasil penelitian dari Puspitasari (2014). Menurut Puspitasari (2014) model terbaik yang digunakan dalam prediksi financial distress adalah model Springate. Penelitian ini juga konsisten dengan penelitian dari Safitri dan Hartono pada tahun 2014. Menurut Penelitiannya model yang paling cocok adalah Springate model

Untuk lebih memperjelas bahwa model Springate adalah model terbaik dan terkuat diantara model Grover dan Zmijewski dalam memprediksi kesulitan keuangan pada perusahaan manufaktur, maka hal yang dilakukan adalah melihat ke dalam komponen yang terdapat dalam model itu sendiri. Komponen tersebut dapat dilihat pada Tabel 7. 
Tabel 7. Komponen Model Grover,Springate, dan Zmijewski

\begin{tabular}{lccc}
\hline \multicolumn{1}{c}{ Komponen } & Grover & $\begin{array}{r}\text { Model } \\
\text { Springate }\end{array}$ & Zmijewski \\
\hline Working Capital To Total Asset & $\mathrm{v}$ & $\mathrm{v}$ & - \\
EBIT To Total Asset & $\mathrm{v}$ & $\mathrm{v}$ & - \\
Net Income To Total Asset & $\mathrm{v}$ & - & $\mathrm{v}$ \\
EBT To Current Liabilites & - & $\mathrm{v}$ & - \\
Sales To Total Asset & - & $\mathrm{v}$ & - \\
Total Debt To Total Asset & - & - & $\mathrm{v}$ \\
Current Asset To Current Liabilities & - & - & $\mathrm{v}$ \\
\hline
\end{tabular}

Sumber: Data diolah (2016)

Tabel 7 memperlihatkan beberapa persamaan dan perbedaan dari ketiga model tersebut. Model Grover dan Springate mempunyai komponen model yang hampir sama dengan model Springate dan model Zmijewski mempunyai sedikit persamaan dengan model Grover. Model Grover dan Springate mempunyai persamaan pada Working Capital To Total Asset dan EBIT To Total Asset, sedangakan Grover dan Zmijewski mempunyai persamaan pada Net Income To Total Asset.

Model Springate lebih unggul atau lebih baik karena memakai 4 komponen yaitu Working Capital To Total Asset, EBIT To Total Asset, EBT To Current Liabilites, dan Sales To Total Asset sedangkan model Grover menggunakan 3 komponen yaitu Working Capital To Total Asset, EBIT To Total Asset, dan Net Income To Total Asset. Grover juga menggunakan 3 komponen yaitu Net Income To Total Asset, Total Debt To Total Asset, dan Current Asset To Current Liabilities. Semakin banyak komponen yang dipakai bisa dikatakan semakin baik dalam memprediksi kesulitan keuangan. Selain melihat komponen dalam model tersebut, rumus dalam komponen tersebut juga harus diperhatikan. Rumus tersebut dapat dilihat pada tabel berikut: 
Tabel 8. Rumus Komponen Model Grover,Springate, dan Zmijewski

\begin{tabular}{lrrr}
\hline \multicolumn{1}{c}{ Komponen } & Grover & $\begin{array}{r}\text { Model } \\
\text { Springate }\end{array}$ & Zmijewski \\
\hline Working Capital To Total Asset & 1.650 & 1.030 & - \\
EBIT To Total Asset & 3.430 & 3.070 & - \\
Net Income To Total Asset & 0.016 & - & 4.500 \\
EBT To Current Liabilites & - & 0.660 & - \\
Sales To Total Asset & - & 0.400 & - \\
Total Debt To Total Asset & - & - & 5.700 \\
Current Asset To Current Liabilities & - & - & 0.004 \\
\hline
\end{tabular}

Sumber : Data Diolah (2016)

Tabel 8 menunjukkan bahwa model Grover lebih menekankan pada EBIT To Total Asset, sedangkan Zmijewski lebih menekankan pada Total Debt To Total Asset. Hal tersebut dapat diartikan bahwa Grover dan Springate menekankan seberapa besar kemampuan aset dalam menghasilkan laba sedangkan Zmijewski menekankan pada seberapa besar kemampuan aset dalam membayar hutangnya.

Komponen yang sangat terlihat berbeda antara model Grover dan Springate adalah dimasukkannya komponen EBT To Current Liabilities yaitu seberapa besar kemampuan laba dalam membayar hutang perusahaan. Komponen ini adalah komponen yang sangat penting bagi kesulitan keuangan karena kesulitan keuangan salah satunya terjadi karena hutang yang tidak tercover oleh perusahaan. Komponen yang membedakannya selanjutnya adalah komponen Sales to Total Asset yaitu seberapa kemampuan asset dalam meningkatkan penjualan perusahaan. Komponen pada Grover dan Springate merupakan komponen yang hampir sama karena acuan yang digunakan oleh model tersebut adalah sama. Model Grover dan Springate mengacu kepada pendesaianan ulang pada model Altman Z-Score. Berbeda dengan model Zmijewski, model tersebut merupakan model yang terbentuk dari riset dan pengalaman tersendiri si peneliti. 


\section{SIMPULAN}

Berdasarkan pada hasil penelitian diatas, maka dapat ditarik kesimpulan bahwa model Springate merupakan model yang memprediksi status tidak sehat terbanyak dibandingkan dengan kedua model lainnya dan memiliki persentse status sehat terkecil diantara kedua model lainnya. Komponen pada Grover dan Springate merupakan komponen yang mendekati sama karena acuan yang digunakan oleh model tersebut adalah sama. Model Grover dan Springate mengacu kepada pendesaianan ulang pada model Altman Z-Score. Berbeda dengan model Zmijewski, model tersebut merupakan model yang terbentuk dari riset dan pengalaman tersendiri si peneliti.

Penelitian ini masih memiliki keterbatasan, yaitu sampel pada penelitian ini hanya perusahaan manufaktur yang terdaftar di BEI, periode pengamatan penelitian ini dibatasi dari tahun 2006-2015, kemampuan prediksi akan lebih baik apabila menggunakan data series yang lebih panjang lagi, penelitian ini tidak memasukkan faktor-faktor di luar rasio keuangan seperti kondisi ekonomi (pertumbuhan ekonomi, tingkat pengangguran, inflasi dan lain-lain) serta parameter politik tidak dapat digunakan dalam penelitian ini karena kesulitan dalam pengukurannya.

Perusahaan agar lebih memerhatikan kondisi eksternal perusahaan dan perekonomian Indonesia yang menyebabkan terjadinya kesulitan keuangan. Selain itu, bagi Kreditor agar melihat secara menyeluruh dan beberapa aspek dari kinerja perusahaan, Untuk Akademisi dapat menambah objek penelitian, tidak hanya perusahaan manufaktur tetapi juga seluruh perusahaan yang listing di BEI.

\section{PUSTAKA ACUAN}

Adriana, A.N. (2012). Analisis Prediksi Kebangkrutan Menggunakan Metode Springate Pada Perusahaan Foods and Beverages yang Terdaftar di Bursa Efek Indonesia Periode 2006-2010. E-Jurnal Repository Akuntansi Universitas Riau, Vol 4 (1): 5-20.

Citrawati, E, \& M. Gede. (2014). Analisis Kesulitan keuangan Altman, Springate, dan Zmijewski pada PT. Fast Food Indonesia, Tbk. E-Jurnal Fakutas Ekonomi 
Universitas Udayana, Vol 6 (3): 379-389

Darsono \& Ashari. (2005). Pedoman Praktis Memahami Laporan Keuangan. Yogyakarta: Andi

Imanzadeh, P.J.M. \& M. Sepehri. (2011). A Study of the Application of Springate and Zmijewski Bankruptcy Prediction Models in Firms Accepted in Tehran Stock Exchange. Australian Journal of Apllied Sciences. Vol 25 (3): 321-335

Husein, P, M. \& T.G. Pambekti. (2014). Precision of the models of Altman, Springate, Zmijewski, and Grover for predicting the financial distress. Journal of Economics, Business, and Accountancy Ventura, Vol 17 (3): 405-416

Lukman, M. \& N. Ahmar. (2015). Model Prediksi Kebangkrutan Fullmer H-Score dan Springate : Mana yang lebih Kuat?. Seminar Nasional Cendikiawan 2015 STIE Perbanas: 12-29

Rahayu, \& Putri. (2016). Analisis penggunaan metode springate (S-SCORE) Sebagai prediktor kebangkrutan (Studi pada Perusahaa Textile yang Terdaftar di Bursa Efek Indonesia pada Tahun 2011-2013. Jurnal Ekonomi Universitas Muhammadiyah Surakarta, Vol 1 (1): 55-68

Puspitasari, W E. (2014). Penggunaan Model Zmijewski, Springate, Altman Z-Score, dan Grover dalam memprediksi kepailitan pada perusahaan transportasi yang terdaftar di BEI. Jurnal FEB Universitas Dian Nuswantoro. Vol 4 (5): 8094.

Sugiyono. (2012). Memahami Penelitian Kualitatif. Bandung: Alfabeta

Springate, Gord, L.V. (1978). Predicting the Possibility of Failure in a Canadian Firm. (Unpublished MBA Research Project). Simoon Fraser University

Wulandary, V \& Nur, E. (2014). Analisis Perbandingan Model Altman, Springate, Ohlson, Fulmer, CA-Score dan Zmijewski Dalam Memprediksi Kesulitan keuangan (studi empiris pada Perusahaan Food and Beverages yang Terdaftar di Bursa Efek Indonesia Periode 2010-2012). JOM FEKOM. Vol 1 No 2: 1-18 
Yami, H, R, N. (2013). Prediksi Kebangkrutan dengan Mengunakan Metode Altman ZScore, Springate, dan Zmijewski pada Perusahaan Properti \& Real Estate yang terdaftar di BEI tahun 2011-2013. Jurnal Fakultas Ekonomi dan Bisnis Universitas Niswantara Vol 1 No 1: Hal 1-12

Zmijewski, M.E. (1984). Methodological Issues Relate to the Estimation of Financial of Financial Distress Prediction Models. Journal of Accounting Research. Vol 22: 59-71. 